\title{
The Position of Local Self-Government in the Constitution of the Republic of Poland ${ }^{1}$
}

\section{Basic assumptions}

The need to strengthen democratic forms and deepen the processes of administrative decentralization poses a challenge for contemporary state systems. For Poland, it is also a condition for effective cooperation with EU Member States, and for becoming a member of the EU in the near future. This is not to state anything new, since these principles have been widely proclaimed ${ }^{2}$ and accepted. However, it is much more difficult to give these processes proper expression in legal form, and even more difficult to implement them in the structure of the state apparatus, especially as the political and economic system is currently undergoing transformation in Poland.

On the legislative level, one of the obstacles is the fact that the legal system is burdened with conceptual constructions from past epochs, and it is often difficult to break free from the outdated language of legal provisions. However, reshaping the contemporary administration requires new legal institutions and that the content of legal acts be updated. As far as actual relations are concerned, apart from basic political issues, one hindrance to change is the lack of recognition of the fact that rebuild-

1 Translated from: T. Rabska, Pozycja samorzq̨u terytorialnego w konstytucji, "Ruch Prawniczy, Ekonomiczny i Socjologiczny” 1995, no. 2, pp. 41-56 by Stephen Dersley. Translation and proofreading was financed by the Ministry of Science and Higher Education under 848/2/P-DUN/2018.

2 In this regard see a very interesting article by E. Schmidt-Assmann, Demokracja i samorzqd w państwie konstytucyjnym, „Samorząd Terytorialny” 1993, no. 11, p. 3; Z. Ziembiński, Wartości konstytucyjne, Warszawa 1993, in particular pp. 73-79. 
ing the state administration is one of the necessary conditions for the transformation of the entire system. A well-known American theoretician who specializes in issues associated with administrative reform wrote: "Administrative reform cannot substitute for political, economic or institutional reform. On the other hand, political, economic, and institutional reforms can rarely succeed without administrative reform.”3

The constitution is the basic legal act that is appropriate for resolving fundamental problems that concern the organization of the state. Presently, there is a unique opportunity to define the foundations and political framework of a modern administration. These decisions cannot be postponed any longer-lack of decision here will constitute a real danger, which could lead to a breakdown in the functioning of public authority and to the tasks of the state not being carried out.

The need for change in this area is completely apparent and widely recognized, ${ }^{4}$ which constitutes both an indispensable condition and a strong incentive for undertaking reforms. ${ }^{5}$ An additional argument in favour of effecting changes is also the fact that many concepts for rebuilding public administration have already been developed, ${ }^{6}$ and more protracted discussion will not contribute anything new.

3 G.E. Caiden, Administrative reform comes of age, Berlin-New York 1991, p. 11.

4 There is a lot of evidence of this, especially in Informacja rzqdu o stanie prac nad reformq "centrum gospodarczego", which was presented in the Sejm on 3 February 1995.

5 Explanations of a range of phenomena concerning introducing changes should also be sought in the theoretical assumptions, in particular the theory of "change management": see The management of change in government, The Hague 1976; J.J. Hesse, Institutional transformation in Central and Eastern Europe: A challenge for public administration and S.A. Pappas, Institutional change and administrative modernization: The transit from a centrally planned economy to a market system, in: Public Administration in the Nineties: Trends and Innovations, Vienna 1992; T. Rabska, Der Übergang von einer zentralen PlanwiHschuft zu einer MarktwiHschaft am Beispiel Polens, Verwaltung und Fortbildung 1993, especially p. $120 \mathrm{ff}$.

6 Work on the reorganization of public administration has been taking place since at least 1991. From the published projects v. Wstępne założenia przebudowy administracji publicznej, Zespół do spraw Reorganizacji Administracji Publicznej, URM, Warszawa 1992; Założenia i kierunki reformy administracji publicznej, Materiały reformy administracji publicznej, Warszawa 1993. 
Local self-government is an integral part of a state system. Therefore, when analysing the position of local self-government and its place in the constitution —and only this issue will be discussed in this article-it must be stressed very strongly at the outset, however, that until a general concept of public administration is developed, efforts to develop local self-government and guarantee it an appropriate place in the executive authorities of the State will continue to encounter significant difficulties. Therefore, it should be expected that at the same time a new and upto-date model of public administration will be established, corresponding to contemporary principles of the organization and functioning of a state in the conditions of a market economy. A change of the economic system absolutely necessitates changes in the state administration and, above all, a departure from centralized management structures. ${ }^{7}$

\section{The Legal Subjectivity of Local Self-Government}

The problems of local government include a number of important legal issues. However, two seem to play a special role in determining the place of local government in the State structure. These are the two legal "pillars" on which the construction of self-government is based: the nature of selfgovernment's legal subjectivity; and decentralization, in close connection with the principle of subsidiarity.

It is indisputable that local self-governments (individual local selfgovernment units) have legal personalities. This is clear from the Constitutional Act of 1952 (Article 70, sec. 2) ${ }^{8}$ and the Local Self-Govern-

7 The introduction of a market economy is also a challenge for the entire public administration. The demonopolization of the state economy requires the democratization and the decentralization of management. Although the interrelations between the economic system and the system of public administration have not been the subject of specific research, the existence of these dependencies is undoubtedly the case. Practice has also revealed the close dependence and regularity of relations between the monopolistic structure of the state economy and the centralization of administration.

8 The Constitutional Statute of 17.10.1992 on the Mutual Relations Between the Legislative and Executive Powers (Journal of Laws, no. 84, item 426, as amended) 
ment Act (Article 2, sec. 2). ${ }^{9}$ This feature is commonly addressed in the scholarly literature. However, the problem is that the legal personality of self-government is understood from a civil law perspective, in a sense equating - from a theoretical and dogmatic point of view-all the legal entities to which the law attributes legal personality (both those that have it by virtue of law and those that acquire it as a result of certain acts, mainly registration). Such a (civil law) conception ${ }^{10}$ of the legal personality of self-government is undoubtedly justified primarily by the separate nature of municipal assets (municipal property) and the fact of its financial independence (having its own budget and independent financial management), as well as by the need for it to act in on its own behalf legal transactions. The municipality meets all the generally recognised requirements of the law in order for it to be attributed legal personality, ${ }^{11}$ and no one has any doubts about this.

In comparison with other legal entities, however, there are positive differences between these entities and the municipality as a legal entity. First of all, it is not the primary task of the municipality to administer assets and make declarations of intent in this respect, on its own behalf and at its own risk. These assets are of great importance for the activities of self-government units, but their management cannot be treated as a means to achieve specific goals. Neither is it a basic task of the municipality to provide services directly to residents in contractual form. This is due to the fact that municipalities are appointed (by law) to carry out public tasks.

9 The Act of 8 March 1990 On Local Self-Government (Journal of Laws, no. 16, item 95, as amended).

10 Such an understanding of the legal personality of self-government is quite common in the literature, see: Kieres, Problemy ustrojowo-prawne samorzqdu terytorialnego, "Samorząd Terytorialny” 1994, no. 12, pp. 12 \& 14; Z. Niewiadomski, Ustrój gminy. Gminne i ponadgminne instytucje samorzq̨u terytorialnego, in: Samorzq̨d terytorialny i rozwój lokalny, Warszawa 1992, p. 157; S. Prutis, Zasady reprezentacji komunalnych osób prawnych w obrocie cywilnym, "Samorząd Terytorialny” 1991, no. 1-2, p. 63; A. Oleszko, Gmina jako osoba prawna, "Samorząd Terytorialny” 1992, no. 6.

11 The concept of legal personality is widely analyzed in the literature on legal theory v. H. Kelsen, Pure Theory of Law, Gloucester 1989, p. 168 ff.; Z. Ziembiński, Problemy podstawowe prawoznawstwa, Warszawa 1980, p. 336. 
They perform these tasks independently, but they cannot independently decide to relinquish their performance. Nobody apart from the legislator may change or take away tasks.

Western European legislation, the development of which has not been impeded by a foreign legal system, attributes public-law personality to such entities. ${ }^{12}$ Pre-war Polish legislation also introduced this concept into legal regulations, ${ }^{13}$ and the construction of legal personality was widely analyzed in juristic literature. ${ }^{14}$ This structure was considered to be of great importance for systemic solutions regarding nongovernmental administration entities.

For the above reasons, this construction was unacceptable in a socialist legal system, being contrary to the principle of a 'uniform' system of power. Along with its elimination from positive law, local self-government was also liquidated, since it was essentially based on a publiclaw personality.

At present, all the prerequisites — both systemic-political, and legal— are in place for the restoration of local self-government. The use of legal concepts in constitutions and statutes that unambiguously resolve fundamental issues concerning the organization and functioning of the state apparatus (in a broad sense) is entirely advisable. The use of such constructions would have a great advantage as a qualifying criterion and would

12 This is indicated by the legal regulations currently in force and the views expressed in literature. In the British system, the construct of 'public corporation' refers to economic entities with a particular legal status. The corporation is understood as "a public authority that pursues public objectives, but is not an entity that is, however, a government entity, nor does its competence overlap with the scope of government”. It fulfils its duties for the public good and not for private profit. On this subject, see the ruling cited in A. W. Bradley, Constitutional and Administrative Law, Longman 1987, pp. 302-303 and the commentary contained therein. The author highlights that currently the legal regulations which create a 'corporation' usually directly define its legal status p. 303. V. J. Schwarze, European Administrative Law, London 1992, particularly pp. 151-152.

13 Articles 65 and 109 of the March Constitution of 1991; Article 75 of the Constitution of 1935; Article 10 of the Act of 23 March 1933 on a Partial Change to the Local Self-Government System.

14 The leading place is occupied by the monograph of T. Bigo, Zwiqzki publiczno-prawne w świetle ustawodawstwa polskiego, Warszawa 1928, which fully preserves its scholarly merit and value to this day. 
allow the legal situation of the self-government and its relation to other state authorities to be settled unambiguously.

It is not my goal to analyze the concept of public-law personality. It occupies a place in both the pre-war Polish legal scholarship and the international literature. ${ }^{15}$ Nowadays, in Polish legal science proposals in this area are formulated very timidly. ${ }^{16}$ It seems important, however, that a number of attributes that the constitution and statutes attribute to local self-government entail that it fulfils the criteria of a public-law person. The interpretation of provisions undertaken by the Constitutional Tribunal is of great help for understanding statutes and determining their significance for the legal construction of self-government. ${ }^{17}$

Polish legislation does not directly introduce the notion of a publiclaw personality or grant the same to local self-government units. However, the Local Self-Government Act, by granting a self-government legal personality by virtue of law (Article 2, sec. 2) at the same time equips it with attributes that other legal persons do not have. ${ }^{18}$ There-

15 As an example, one should mention: T. Bigo, Zwiq̨zki publiczno-prawne...; A. Peretiatkowicz, Podstawowe pojęcia prawa administracyjnego, Poznań 1947, p. 28 ff.; E. SchmidtAssmann, Demokracja i samorzq̨...., in particular p. 5. J. Schwarze, European Administrative..., pp. 151-152, clearly distinguishes three types of entity: 'central administration', 'public corporation' and 'local authority'.

16 V. W. Miemiec, M. Miemiec, Podmiotowość publiczno-prawna gminy, "Samorząd Terytorialny” 1991, no. 11-12, p. 19; R. Turpin, Określenie własności i osób prawa publicznego, "Rzeczpospolita" 8 XI 1994. The latter states that Article 2.2 of the Local Self-Government Act does not define the legal nature of legal personality. "This system deficiency can be supplemented only by the relevant constitutional norm.”

17 I am referring in particular to the ruling of the Constitutional Tribunal of 27 September 1994, W. 10/93. Although its main purpose is to interpret Articles 85 and 87 of the Local Self-Government Act and to explain the expression 'municipal activity', it nevertheless formulates a number of important conclusions regarding the tasks and activities of the local self-government itself; see "Rzeczpospolita” of 2 November 1994, pp. 17-18.

18 T. Bigo states: "Legal personality is one in the whole area of law. It is the ability to become the subject of rights and obligations. The conceptual distinction of the so-called public-law personality is a false method. In truth, certain legal organizations with legal personality can occupy a special position in the State (e.g. Independent divisions, public law associations). The justifications for this distinction cannot be sought in the very essence of the legal personality, since this is always the same. Answers to the question of what this particular position consists in must be sought in positive law”; T. Bigo, Zwiqzzi publiczno-prawne..., p. 27. 
fore, this justifies treating the legal personality of a self-government at least as a very specific form of personality. The most important prerequisites include the following:

- participation of local self-government in the exercise of power (Article 5 of the Constitution)

- the establishment of self-government for the purpose of performing public tasks and the public character of self-government objectives recognised by the State; this is clearly defined in the provisions of the Constitutional Act (Article 71) and the Local SelfGovernment Act (Article 4, sec. 2, Article 6, Article 97, sec. 1);

- the tasks performed by local self-governments do not differ in kind from the tasks of the State, they perform the functions of the State. The division of tasks between self-government and government bodies is determined by formal and legal criteria, and not by a specific type of tasks (Article 71 of the Constitutional Act and Article 6 of the Local Self-Government Act $)^{19}$;

- the legal existence of self-government is based on statute. The establishment, transformation or merger of individual local selfgovernment units is decided by the state authorities (Article 4 of the Local Self-Government Act). Members ("community residents") cannot dissolve local government ${ }^{20}$;

- the membership of "community residents" in a given local self-government unit is created ipso iure (Article 1 of the Local Self-Government Act);

- being equipped with the same legal means of action as the state administration, the application of coercive measures by local self-government organs, and the execution of administrative du-

19 This is definitely the view of T. Bigo: "In my opinion, the content of the activities of selfgovernment associations is not where one could find the criterion of separateness [...]. In terms of content, the activities of self-government associations do not reveal any separateness”. Ibidem, pp. 58-59.

20 This feature of local government is strongly emphasized by T. Bigo, Zwiqzki publicznoprawne..., p. $57 \mathrm{ff}$. The Constitutional Tribunal also referred to local government as a "compulsory link”. Ruling of the Constitutional Tribunal of 27 September 1994, W. 10/93. 
ties of a non-monetary nature (Articles 39 and 102 of the Local Self-Government Act and the Law on Administrative Enforcement Proceedings). ${ }^{21}$

It is clear from the above that local self-government was equipped by law with specific attributes - the attributes of a public authority. ${ }^{22}$ It may constitute legal norms for other entities by virtue of law, without their consent. Such a legal person, having administrative power, must be considered a public-law person.

On the basis of administrative law, these features render the position of self-government bodies equal to those of government administration bodies. At the same time, they differ fundamentally from other legal entities (under a given legal system) which do not have such competences.

The legal personality of self-government is associated with a number of specific attributes, while at the same time it is to some extent limited by the public purposes for which the self-government was established. ${ }^{23}$

The recognition of the public-law nature of local self-government has a number of important consequences. They result from the very foundations of the political and economic system of the State. The obligation falls on the self-government (its organs) to respect the laws of the Republic of Poland and to act on the basis of legal regulations on the same principles as "every state organ" and "all organs of authority and state administration" (Article 3, sec. 1 and 2 of the Constitution). ${ }^{24}$ The activity of local self-government is also subject to all the other principles of the new system. Therefore, local self-government is obliged to guarantee within its territory freedom of economic activity, regard-

$21 \mathrm{~V}$. the Act of 17 June 1966 on executive proceedings in administration, Journal of Laws 1991, no. 36, item 161, in particular Articles 1-3, 20.

22 The Constitutional Tribunal states this unambiguously; cf. the cited judgment, p. 18.

23 Here, of particular relevance is the characteristic position of A. Bradley on the legal capacity of local authorities, the law based on the purposes for which that power was established.

A. Bradley, Constitutional and administrative law..., p. 382.

24 The applicability of the same rigors in the activities of local self-government as those applicable for all state organs is raised by the judgment of the Constitutional Tribunal. See also an interesting judgment of the Supreme Court, in which it was concluded that the principle of "what is not prohibited is allowed" does not apply to municipalities. 
less of the form of ownership (Article 6 of the Constitution). This has a significant impact on the position of local self-government organs in the field of economy in general, as well as on the type and scope of their own activities in this field.

In order to express these special situations in the language of legal acts, the institution of public-law personality is introduced. The attributes of local government set forth in legal provisions justify the application of this construction directly in the constitution and local government acts.

Among the various drafts of the constitution currently under discussion, only the draft of the President of the Republic of Poland contains a provision stating that "local self-government units have public-law personality as existing under the law of the community of residents of a given territory” (Article 80, sec. 2 of the draft).

\section{The Dysfunctional Provisions of the Constitutional Act of 1952}

Recognition of the public-law personality of local self-government units was to have far-reaching consequences in many spheres, especially in terms of determining the place of local self-government units in the structure of state organs. In this respect, constitutional regulations would also require reconstruction.

Not only did the Constitutional Act of 17 October 1992 and the contents of a number of its provisions fail to enable clear determination of the place of local self-government in the system of state organs, but it also raises many fundamental doubts. For example, the suggestion that local self-government is a fourth power in the State (next to the legislative, executive and judicial powers) would not be unfounded. In any case, it could be assumed that local self-government occupies a position outside the executive power. The following constitutional determinations could lead to such a conclusion: 
- Firstly, the title of the Constitutional Act of 1992 itself, "on mutual relations between the legislative and executive powers of the Republic of Poland and on local self-government” might suggest that the Act concerns two completely separate spheres of systemic issues. Meanwhile, there should be no doubt that the relationship between the legislative and executive powers should - at least to a certain extent-depend on the nature of the executive powers (the degree of its democratization, the nature of organizational structures, etc.);

- Secondly, Article 1 of the Constitutional Act of 1992 establishes the state organs in the area of individual powers, and in the area of executive power enumerates: The President of the Republic of Poland and the Council of Ministers, leaving open not only the issue of public ("state") administration ${ }^{25}$, but also that of local self-government. This self-government is regulated in a separate chapter of the Act (chapter 5), in principle without any connection with the others. ${ }^{26}$

- There is, therefore, a clear dysfunctionality in the systemic provisions. ${ }^{27}$ Such a state of affairs indicates the inconsistency of legal solutions and, above all, the lack of a comprehensive vision

25 The issue concerns the legal position of the minister, for which the legislator uses the content of an article taken directly from the Constitution of 1952. At present, it is Article 56 of the Constitutional Act of 1992 which stipulates that "the Minister shall manage a specific department of state administration. The scope of activity of the minister is defined in the Act”. The issues of public administration have been completely omitted, and only Article 69 concerns a voivode in this respect, referring to it as a "governmental administration organ" (previously referred to as "state administration"). Therefore, in this situation it is difficult to speak about any legal model of public administration.

26 This gap cannot be filled by the sole provision that "the Council of Ministers [...] shall exercise, within the limits and form as defined in the Constitutional Act and other laws, supervision over local self-government and other forms of local government...” Article 52, sec. 2, item 1 of the Constitutional Act. All the more so as the Constitutional Act states that "Supervision over the activity of local self-government units shall be determined by statute” (Article 74). The Act on Local Self-Government entrusts supervision to the Prime Minister (Article 86).

27 On the dysfunctionality of the Constitution, V. S. Wronkowska, Kilka uwag w sprawie funkcjonalności i dysfun - kcjonalności konstytucji, "Ruch Prawniczy, Ekonomiczny i Socjologiczny” 1995, facsim. 1, p. 3 ff. 
when it comes to public administration. The negative impact of this legal status on the actual functioning of public administration as a whole is indisputable. ${ }^{28}$

\section{New Guarantees for Decentralization Processes - the Principle of Subsidiarity}

The structure of contemporary, modern administration should be based on the principles of decentralization and subsidiarity ${ }^{29}$, and they should be introduced into the organisational structure of administration in close connection with each other. One should therefore speak of the principle of decentralization (in its classical sense), enriched with the principle of subsidiarity, and the principle of "at the level of the nearest citizen" (which will be covered later).

The European Association Agreement ${ }^{30}$ and the prospect of membership in the European Union oblige Poland to adapt its administrative structures in alignment with commonly respected principles. ${ }^{31}$ It does not seem possible that a State with a centralized administration would

28 A broader and more detailed analysis of this fundamental problem for the country's political system is beyond the scope of this article.

29 The principle of subsidiarity, derived from the social teachings of the Church, is undergoing a great renaissance in the donation law of the European Union and there is quite extensive literature on the subject. See in particular D. Lasok and Bridge, Law and Institutions of the European Union, Butterworths 1994, pp. 36-38; The Principle of Subsidiarity, in: Communication of the Commission to the Council and the European Parliament, Brussels 1992; F. Norall, A. Sutton, The European Crisis, The Maastricht Treaty and the Future of the European Community, Brussels 1992, p. 15 ff.; and from Polish scholarship: M. Radwan, Zasada pomocniczości w polityce regionalnej EWG, “Samorząd Terytorialny” 1993, no. 9, p. 12 ff.

30 The European Association Agreement, which establishes an Association between, on the one side, the Republic of Poland and, on the other side, the European Communities and their Member States; Journal of Laws of 1994, no. 11, item 38.

31 A few years ago, S. Cassese wrote "Public administrations and their administrative law systems are considered to be the last enclaves of nationalism"; S. Cassese, Toward a European model of Public Administration, in: Comparative and Private International Law, Berlin 1990, p. $353 \mathrm{ff}$. 
be able to cooperate with decentralized European structures. ${ }^{32}$ Relations within a national administration should not differ significantly from those prevailing in the EU.

Therefore, it would be appropriate to transfer the relevant applicable provisions of European acts in this respect to internal relations. The Treaty of the European Union, as adopted at Maastricht on 7 February $1992^{33}$, states that "This Treaty marks a new stage in the process of creating an ever closer union among the peoples of Europe, in which decisions are taken as closely as possible to the citizen.” Although this provision refers directly to the organization and functioning of the European Union, the idea of the Union can only be fully realized if this principle is transposed to and respected in national relations.

As far as local self-government is concerned, the European Charter of Local Self-Government contains a provision which is fundamental and directly binding for our country. ${ }^{34}$ Article 4(3) of the Charter reads: "Public responsibilities shall generally be exercised, in preference, by those authorities which are closest to the citizen.” This document therefore directly concerns the internal relations of the administration and the scope of the activities of local self-government. The Charter has become a part of the Polish legal order. By ratifying it, Poland pledged to that the Charter "will be inalterably maintained."

The principle of subsidiarity is equally important for the system of relations between various organs. It significantly enriches the issues associated with building organizational structures, introducing essential elements concerning the criteria for the division of tasks undertaken in these structures. These are the criteria which concern the object of

32 The issue of contemporary state administration structures is a subject of growing interest in the West; see. e.g. J. Usher, Principles of Good Administration. The Continuing Development of Law and Institutions..., p. $33 \mathrm{ff}$.

33 The Maastricht Treaty of 7 February 1992 came into force on 1 November 1993, introducing a number of significant changes to the Treaty of Rome of 1957. For this reason, a debate was begun in the West on whether a Constitution of a United Europe should not be drawn up.

34 Cf. European Charter of Local Self-Government, drafted in Strasbourg on 15 October 1985, ratified by Poland on 26 April 1993; Journal of Laws of 1994, no. 124, item 607. 
decentralization, and thus are of a substantive nature. The principle of subsidiarity has become one of the fundamental principles of European constitutional law, as the commentators of European law unanimously emphasize. ${ }^{35}$

In the light of the provisions of the Treaty on European Union (Article B in fine and Article 3b), the Community should take action "only if and in so far as the objectives of the proposed action cannot be sufficiently achieved by the Member states and can therefore, by reason of the scale or effects of the proposed action, be better achieved by the Community”, and the objectives of the Community can only be attained "in accordance with the principle of subsidiarity...".

Again, it must be made clear that the provisions of the Treaty refer to the Member States of the Union and directly concern the relations between the Union and these countries. Indirectly, however, they should be reflected in internal state agreements. In reality, their internal application depends on constitutional traditions. ${ }^{36}$

This new content should be reflected in the provisions of our Polish Constitution. If the Constitution is to be a modern act, and only such should be considered, then its role should not be limited to 'correcting' existing structures when applying old legal constructions. The changes should be comprehensive and far-reaching. In order for the new institutions to be effective, changes should include the entire local self-government and government administration.

The basic conclusion that can be drawn from the above is that decentralization processes must be consistently implemented with their new content. Entities with public-law personality ensure their implementation to the fullest extent. Decentralization is thus an inherent feature of

35 F. Norall, V.A. Sotton, op.cit., p. 15 ff.; D. Lasok, Law and Institutions of the European Union, Butterworths 1994, p. 37.

36 An example of this is provided by the Federal Republic of Germany. This rule was used primarily to determine the scope of the economic activity of local self-government associations. 
local government. ${ }^{37}$ Decentralized self-government bodies by definition carry out public administration, independently, at the level closest to the citizen. Activities undertaken by higher public authorities should be limited.

Legal science also distinguishes functional decentralization. ${ }^{38} \mathrm{Al}-$ though it must be admitted that this form of decentralization can also be useful in 'perfecting' the administrative apparatus, it cannot fundamentally and qualitatively change the structure of the entire administration. Functional decentralization means that changes are made within the central government apparatus itself. Therefore, it would be difficult to agree with the view that, for example, increasing the independence of the voivodeship, as a component of the government administration, may contribute to strengthening the position of self-government ${ }^{39}$.

According to D. Lasok, "Subsidiarity is opposed to centralism and the unnecessary exercise of power (central government) directed downwards" ${ }^{40}$. The issue of 'subsidiarity' being opposed to central-

$37 \mathrm{~T}$. Bigo indicated the particular significance of the element of decentralization in the construction of local self-government, T. Bigo, Zwiqzzi publiczno-prawne..., pp. $120 \mathrm{ff}$. He held that decentralization is an element that distinguishes public-law associations from government administration and other types of administration. On the other hand, he clearly stressed that the local self-government does not exhaust the forms of decentralization, as it is only one of its types T. Bigo, Zwiq̨zki publiczno-prawne..., p. 124.

38 The problem of functional decentralization was raised in particular in the German science of administrative law particularly in the work of H. Siedentropf. See also Institutional change and administrative modernization: The transit form a centrally planned economy to a market system. S.A. Pappas defines functional decentralization as a "process in which tasks, competences and responsibilities are transferred to public authorities, while the ministerial responsibility is of a limited nature. There is no hierarchical connection between the minister and the agency" (Public Administration..., p. 142).

39 V. L. Kieres, Problemy ustrojowo-prawne samorzq̨du terytorialnego, „Samorząd Terytorialny" 1994, no. 12, p. 14. Admittedly, the position of local self-government will depend on the change in the status of government administration bodies, but it is doubtful that increasing the independence of the local government administration body could have a positive impact on the situation of municipal self-government.

40 V.D. Lasok, Law and Institutions..., p. 36. The author further writes that 'subsidiarity' may serve to check the excessive tendency towards centralism and in this sense may act as a brake on the accidental actions of the Union institutions, on the ambitions of their bureaucracy. Ibidem, p. 38. 
ized decision-making systems is raised in the documents of the EU bodies and in the Western literature ${ }^{41}$. It may come as a surprise that elements of subsidiarity can also be found in pre-war Polish legislation. An example is the Sanitary Act of 1919, in which, at the end of Article 1, it is stated that: "Care for the health of the population and direct execution in this regard is the obligation of local self-government bodies within the territories entrusted to them, under the supervision and care of the state authorities ${ }^{42}$. This task of 'caring' for the execution of public tasks (a notion which had been hitherto rather alien to our legislation) should be properly defined and developed in legal provisions (however, this is not to be confused with the concept of the "welfare state").

Local administration cannot, therefore, in the light of these fundamental general principles, operate only on the fringes of state activity, or be limited to the exercise of functions ancillary to the central government, which would bring together all the powers. In modern systems these relations have been reversed.

Such assumptions should also have an impact on the scope of the tasks delegated to the local self-government, i.e. those tasks that the government administration delegates to the local government, but which remain in the power of the government apparatus. Here too, the division of tasks should be appropriately selected from the point of view of the requirements of the new rules, and taking into account the proper relations between the local self-government's own tasks and the tasks delegated to it. This would not entail the complete abandonment of this form of delegation from the central to the local government. There should be no doubt that there are certain categories of public tasks that can or should be centrally managed for various reasons. It is therefore a matter of adopting appropriate criteria for division.

The adoption of the principle of subsidiarity, as a complementary and content-building principle of decentralization, entails yet other spe-

41 See especially F. Norrall and A. Sutton, The European Crisis..., p. 3.

42 The Basic Sanitary Law of July 19 1919, Journal of Laws of 1919, no. 63, item 371. 
cial consequences. Namely, this principle could be an effective barrier against the permanent limitation of the scope of tasks and independence of local authorities and their secondary takeover (by various means) by the central authority. A common practice that accompanied all administrative reforms was that the competences granted at the time of the reforms were then returned (in various ways) back to the central level, or - at least - were gradually and significantly reduced. In principle, there were no guarantees that could hinder such processes. With the adoption of the subsidiarity principle, which would define permanent criteria for the allocation of tasks, decentralization processes would be clearly supported. The allocation of public tasks could not result from changing directions of government policy, but would be based on principles that are not subject to arbitrary evaluation. It is precisely the tasks - their character and scope - that should determine the organizational structures that meet their needs. The basic assumption should be that organizational solutions should match the tasks, and not vice versa. That the opposite processes are in operation is evident if the structures remain intact while tasks are shifted within their framework (this is-so far-the frequent scenario of reforms).

\section{The Privatisation of Public Tasks - Economic and Professional Self-Government}

A particular (and recent) direction of transformations in the field of public administration is the privatization of public tasks ${ }^{43}$. Therefore, it can be assumed that the privatization of public tasks will constitute the next stage in the transformation of public administration activity. In such

43 The issue of the privatization of public tasks takes on great importance in Western practice and scholarly literature. See, for example, R. Schmidt, Die Privatisierung öffentlicher Aufgaben aid Problem des Staats - und Verwaltungs rechts, in: Grundfragen des Verwaltungsrechts und der Privatisierung, Stuttgart-München 1994, p. 210 ff. In Polish scholarship, this problem was presented in a comprehensive way by S. Biernat, Prywatyzacja zadań publicznych. Problematyka prawna, Kraków 1994. It should be noted that "privatization of public tasks" can be understood in different ways cf. ibidem, p. $25 \mathrm{ff}$. 
a situation, there could be a kind of competition between different ways of achieving transformation, namely, between the decentralization of public administration on the one hand, and the privatisation of public tasks on the other - which would also have an impact on the position of local self-government.

From the perspective of legal theory, there are basically two different issues to be resolved, at different levels: structural and functional. These changes can therefore take place in parallel. However, it seems to be indisputable that privatizing public tasks should lead to a reduction of the public administration apparatus (both centralized and decentralized).

Although it may be understood in different ways, the privatization of public tasks consists in removing a specific task (or part of it) from administrative structures. ${ }^{44}$ An example of privatization may be private schools, private clinics, i.e. matters traditionally falling under the remit of the State and undertaken by the public administration. Decentralization, on the other hand, means a qualitative change in organisational arrangements, the independence of individual administrative entities, and a different distribution of public tasks. Both the administrative apparatus and the tasks remain public. ${ }^{45}$

It can be assumed that in the future the privatization of public tasks and their assumption by private entities will give rise to a natural tendency for these entities to associate. In this way, apart from local self-

44 The American and English literature indicate different understandings of 'privatization'. V. E.S. Savas, Prywatyzacja. Klucz do lepszego rzqdzenia, Warszawa 1992; T. Prosser, Privatisation and Regulation, in: The legal control of public power in Europe, London 1994.

45 I analyzed the concept of centralization more broadly in the work Samorzqd robotniczy w PRL (1962), especially pp. $10 \mathrm{ff}$. The concept of decentralization is most clearly characterized by T. Bigo, Zwiqzzki publiczno-prawne..., p. 120. He emphasizes in particular that "Decentralization means a system in which there is a greater number of public administration centers", that administer independently. He adds further, and characteristically: "Ex definitione it follows that there must be one administration center behind these independent centers, a source of common norms that maintain unity, but they have independence in relation to this center”. T. Bigo, Zwiq̨zki publiczno-prawne..., p. 121. 
government, other forms of self-government-economic, professional, cultural, religious, etc.-may develop more intensively. ${ }^{46}$

In my opinion, it would be difficult to express directly in the Constitution the idea of the privatization of public tasks in any other way than through the freedom to pursue professions (as in the German Constitution ${ }^{47}$ ) and the guarantee of freedom of economic activity. This is, however, an issue that goes beyond the scope of this paper. On the other hand, it would already be possible to introduce into the Polish Constitution provisions on fundamental issues related to the economic and professional self-government, without referring all the regulations to future laws (as is currently the case). Such a reference is a blank provision, which makes a given institution completely dependent on ordinary legislation. Meanwhile, this issue has become a political issue and requires solutions on the constitutional level. This is evidenced, inter alia, by the disputes that are already taking place over the draft act On Economic Self-Government. ${ }^{48}$

\section{The Development of the Structure of Local Self-Government}

The issue of the territorial division of the State for administrative purposes is a separate issue. The territorial grid is the spatial basis for the administration. Making this division should be justified first of all by the types of public tasks and their scope, based on the criterion of rationality. There is also talk of the criterion of the "administrative capacity"

46 For more detailed discussion on economic self-government, v. T. Rabska, Rechts - und Organisationsfragen der Wirts chaftlichen Selbstverwaltung.

47 Article 12, sec. 1 of the Basic Law of the German Federal Republic guarantees the right to free choice of profession, place of work and education. Also Article 2 sec. 1, which stipulates: "Everyone has the right to free development of their personality". Grundgesetz für die BRD of 23 May 1949, as amended. Both of these constitutional provisions have extensive case-law.

48 The draft law on economic self-government, Sejm Print no. 132 of 16 November 1993. 
of territorial units ${ }^{49}$ with regard to the implementation of specific public tasks. On the other hand, the question of the nature of the administrative entity should not have—at this stage and in these matters—-decisive significance. For this reason, neither territorial division nor the number of territorial division units (or possibly their size) will be considered here. ${ }^{50}$

Once again, we arrive at the fundamental problem, namely the dependence of the position of local self-government on the general conception of public administration, taking into account all the elements that are included within the scope of this concept. Until the concept of state administration is defined as a whole, the further development of local self-government and the establishment of its position in the Basic Law will encounter fundamental difficulties. Without this, the adoption of any concept of local self-government will be implemented in a systemic vacuum, in an uncertain structure of state organs, the formation of which would depend on the centralized organs of the central administration. In any case, on the basis of the experience gained so far, it can be concluded that a single-level self-government organization established only at the municipal level does not yet sufficiently implement the principles of the decentralization of public administration. The curtailment of further development of local self-government and the failure to implement further decentralization processes has led to an inevitable confrontation between the decentralized local self-government administration and the entire remaining, large machine of hierarchical central administration, which is constantly expanding and maintaining departmental divisions. This imbalance in the structural and competence systems seriously endangers the proper functioning of the entire executive

49 It is worth pointing out the very interesting materials on the administrative division of the State, developed in 1931. Materiały Komisji dla usprawnienia administracji publicznej, especially vol. V, Warszawa 1931, p. 14 ff.

50 I addressed the problem of the spatial division of the public administration in the article Refleksje na temat układu przestrzennego administracji publicznej i jego konsekwencji w zakresie administrowania, "Ruch Prawniczy, Ekonomiczny i Socjologiczny” 1992, facsim. 2, p. 25 ff. 
apparatus. This state of affairs, which is more than evident in current government practice, can no longer be maintained.

Therefore, there is now an urgent need to introduce into the new constitution such provisions that would directly determine the development of local self-government to higher levels and extend the participation of local self-government in the exercise of public authority.

The consequence of expanding local self-government by further links would be the creation of a whole system of local government bodies, operating at various levels of territorial division. Therefore, within the organisational framework of local self-government, new relations will be established between local self-government units and their organs. The problem is of particular importance and its significance for the functioning of the whole institution in the future cannot be disregarded. ${ }^{51}$ Hitherto, only issues concerning the mutual relations between local self-government bodies at the same level have been subject to regulation, i.e. the legislative and executive body of the municipality, and therefore within the same self-government unit. The establishment of a higher level of self-government (powiat - county) or higher levels (powiat and voivodeship) would at the same time require a clear definition of the mutual relations between different self-government units, whose areas of activities overlap.

Contrary to popular opinion, it does not seem realistic to base these relations on the principle of the total separation of each link, nor does it seem possible to make such a separation of public tasks which would focus on only in one level of the complex self-government organization. Moreover, I do not think that it is advisable to pursue such an aspiration. The performance of tasks cannot be separated from the area in which they are executed, nor can the residents be separated according to the public services provided. It would also be unacceptable to assume

51 I am raising this problem because the draft bill On County (Powiat) Self-Government and the ongoing discussions concerning county (powiat) self-government seem to completely avoid this problem. Sejm Printed Document, no. 295 of 29 January 1995. 
that higher-level self-government organs do not represent the entire community living in a given area, but only the group that would benefit from their services. This would, above all, contradict the principle of the universality of the institution of local self-government.

On the other hand, one feature of self-government is that each of its links (each local government unit) is an independent legal entity and constitutes a decentralized public administration entity. This means that a lower link of the self-government is not dependent on a higher link. Therefore, there can be no talk of any kind of supremacy and subordination, because that would deny the legal essence of self-government. Another issue, however, is the need for cooperation and mutual solidarity wherever it is necessary due to the commonality of residents and the area inhabited by them. Thus, when entrusting tasks to a higher-level self-government unit, the legislator should take into account—as the European Charter of Local Self-Government states- "the extent and nature of the task and requirements of efficiency and economy” (Article 4(3)).

Recognition of the need for mutual cooperation between local self-governments and their unity as a political institution would support the need to establish a general national self-government representation, which would crown the entire system. An organization of this kind would have to in fact unite all local government units, by virtue of the law. Its existence would be independent of the possibility of establishing and operating other self-governing associations as well, on a voluntary basis, connecting only particular groups of self-government units, based on the criterion of common (group) interests and the joint performance of specific public tasks.

The issue of establishing a national association is potentially controversial, although in principle it would only involve formalizing an institution which, from the very beginning of the introduction of local self-government, has been established by the representation of mu- 
nicipalities and which actually operates without any special legal authority. ${ }^{52}$

\section{The Conditions for Co-Responsibility for Public Administration}

The paper presents some of the legal conditions of local self-government and those issues whose introduction into the public administration system requires unambiguous constitutional regulations. Leaving these matters to future statutory regulation (by means of a stereotypical reference: “... will be determined by law") ${ }^{53}$ would be an irreversible mistake and would amount to a missed opportunity to restructure the administration.

Summarizing the above, it is only possible to provide a general outline of the issue and a few important aspects. However, I am of the view that the issues raised here allow us to conclude that reducing the transformations of the public administration today solely to the matter of appointing counties (powiat) or not, and the heated debates about them, constitutes a big misunderstanding. It is proof that we do not understand the catastrophic state that the entire public administration is currently in, and that we fail to appreciate the extent of the reconstruction necessary for today's administration as a whole — on both central and local levels. The matter requires a completely new vision of public administration, built on different principles, and not only a part of the local self-government organization (although this is of great importance).

The dysfunctionality of the whole structure of the executive apparatus runs so deep that the 'self-government issue' cannot be separated from the entire public administration. From the beginning of the transformation

52 V. L. Kieres, Problemy ustrojowoprawne samorzqdu terytorialnego, "Samorząd Terytorialny" 1994, no. 12, especially p. 14 ff. Inter alia, I expressed my view on the need to formally regulate the status of the existing representation of national self-government, namely the National Assembly of Local Self-government, in the article, Możliwości zmian ustawy o samorzq̨dzie terytorialnym, "Samorząd Terytorialny" 1994, no. 10.

53 This form of 'delegation' is used in the Constitutional Act of 1992, and in matters of fundamental importance concerning the local self-government, e.g. Article 70 sec. 4, Article 74-75. 
of the political and economic system, there was little appreciation of the fact that there is a need to adapt the state administration to the completely new state tasks in the changing economic system, and to the requirements of effective action. The links between the transformation of the economy and the administration were not sufficiently taken into account, especially when the 'inherited' administration was shaped entirely for the needs of the bureaucratic system of a centrally planned economy. ${ }^{54} \mathrm{Cur}$ rently, the situation is deteriorating, not only due to the time that has been wasted, but also due to the fact that the current views of politicians do not demonstrate a will to change the administration model..$^{55}$

Under applicable law, it is even difficult to determine what constitutes 'public administration'. It is not a question of the theoretical understanding of this term, as there have always been problems of this nature in legal science. The issue concerns the legal situation and its consequences for the functioning of the executive power. It also concerns the constitutional provisions of 1992, the legislation in force, and drafts of the future constitution. Apart from solving issues of a systemic nature, the aim is also to ensure the correct application of law.

The term 'state administration' is most frequently used in legislation, however, it is not possible to determine without reservation which circle of entities this term covers. It would be useful to introduce the term 'public administration' into legislation, as a broader term covering central and local administration, government administration and

54 These problems were widely discussed in the research project KBN no. 1-1016-91-01 Struktura, zadania i formy działania naczelnego aparatu administracji państwowej w zmienionym ustroju gospodarczym by T. Rabska, Typescript in the Library of the Faculty of Law and Administration of Adam Mickiewicz University in Poznań; see in particular part VIII - Syntetyczny opis wyniku końcowego.

55 Just by way of example, see Strategia dla Polski, Sejm Printed Document, Print no. 447 of 7 June 1994, especially the part concerning the reform of the 'economic center', and critical debate in the Sejm in February 1995 on "Government information on the state of work on the reform of the 'Center'”. The content of the new 'coalition agreement' also testifies to the lack of real desire for change. On the other hand, with regard to changing the local administration model, the Speaker of the Senate of the Republic of Poland and the Chairman of the National Assembly of Local Self-Government said: "This is not the most urgent matter at present in terms of stabilizing the situation in Poland”. Ibidem, p. 5. 
local self-government administration. It is precisely the application of the concept of public-law personality that would justify such a unification. Consistent use of the appropriate language of legal acts would make it possible to determine, in each case, to whom the legal act is applied, who is bound by it, or with regard to which group of entities a given competence may be exercised. In the light of the current language of legal acts and the meaning of the term 'administrative state administration', such issues often cannot be explicitly resolved, nor is it possible to decide whether the term 'state administration' as used in a given case also encompasses local self-government. ${ }^{56}$

The ongoing work on the draft Constitution creates a real chance to outline the basic political framework-structural and functionalof the entire public administration. The need for deep decentralization through the recognition of various public administration entities (government and local self-government), and at the same time the need to pursue common goals, places local self-government high in the hierarchy of executive power organs responsible for the functioning of the State. The foundations of this shared responsibility, i.e. the real division of executive power (with all the consequences this entails), can only be established by an act of the same status as the Constitution, and this is to be expected from the Constitution in the first place. However, making changes only within local self-government-although undoubtedly necessary - may ultimately have a negative impact on the institution of local self-government itself. Given the current poor state of public administration, it seems rather improbable that only one member of the public administration would be able to bear the weight of reforms.

56 Many examples are already provided by the Constitutional Act of 1992; cf. Article 51 sec. 1, para. 2 items 3 and 6; Article 56, Article 69, Article 34 on the Supreme Audit Office (NIK) (maintained in force pursuant to Article 77). However, correctly - Article 71. 


\section{References}

Biernat S., Prywatyzacja zadań publicznych. Problematyka prawna, Kraków 1994.

Bigo T., Zwiq̨zki publiczno-prawne w świetle ustawodawstwa polskiego, Warszawa 1928.

Bradley A.W., Constitutional and Administrative Law, Longman 1987.

Caiden G.E., Administrative reform comes of age, Berlin-New York 1991.

Cassese S., Toward a European model of Public Administration, in: Comparative and Private International Law, Berlin 1990.

Hesse J.J., Institutional transformation in Central and Eastern Europe: A challenge for public administration, in: Public Administration in the Nineties: Trends and Innovations, Vienna 1992.

Kelsen H., Pure Theory of Law, Gloucester 1989.

Kieres L., Problemy ustrojowoprawne samorzqdu terytorialnego, “Samorząd Terytorialny” 1994, no. 12.

Lasok D., Law and Institutions of the European Union, Butterworths 1994.

Miemiec W., Miemiec M., Podmiotowość publiczno-prawna gminy, "Samorząd Terytorialny" 1991.

Niewiadomski Z., Ustrój gminy. Gminne i ponadgminne instytucje samorzq̨du terytorialnego, in: Samorzq̨d terytorialny i rozwój lokalny, Warszawa 1992.

Norall F., Sutton A., The European Crisis, The Maastricht Treaty and the Future of the European Community, Brussels 1992.

Oleszko A., Gmina jako osoba prawna, "Samorząd Terytorialny” 1992, no. 6.

Pappas S.A., Institutional change and administrative modernization: The transit from a centrally planned economy to a market system, in: Public Administration in the Nineties: Trends and Innovations, Vienna 1992.

Peretiatkowicz A., Podstawowe pojęcia prawa administracyjnego, Poznań 1947.

Prosser T., Privatisation and Regulation, in: The legal control of public power in Europe, London 1994. 
Prutis S., Zasady reprezentacji komunalnych osób prawnych w obrocie cywilnym, "Samorząd Terytorialny” 1991, no. 1-2.

Rabska T., Der Übergang von einer zentralen PlanwiHschuft zu einer MarktwiHschaft am Beispiel Polens, Verwaltung und Fortbildung, 1993. Radwan M., Zasada pomocniczości w polityce regionalnej EWG, "Samorząd Terytorialny” 1993, no. 9.

Ruling of the Constitutional Tribunal of 27 September 1994, W. 10/93.

Savas E.S., Prywatyzacja. Klucz do lepszego rzqdzenia, Warszawa 1992. Schmidt R., Die Privatisierung öffentlicher Aufgaben aid Problem des Staats - und Verwaltungs rechts, in: Grundfragen des Verwaltungsrechts und der Privatisierung, Stuttgart-München 1994.

Schmidt-Assmann E., Demokracja i samorzq̨ w państwie konstytucyjnym, "Samorząd Terytorialny” 1993, no. 11.

Schwarze J., European Administrative Law, London 1992.

Turpin R., Określenie własności i osób prawa publicznego, "Rzeczpospolita” 8 XI 1994.

Wronkowska S., Kilka uwag w sprawie funkcjonalności i dysfunkcjonalności konstytucji, “Ruch Prawniczy, Ekonomiczny i Socjologiczny” 1995. Ziembiński Z., Problemy podstawowe prawoznawstwa, Warszawa 1980. Ziembiński Z., Wartości konstytucyjne, Warszawa 1993. 


\section{SUMMARY}

\section{The Position of Local Self-Government in the Constitution of the Republic of Poland}

The paper is an English translation of Pozycja samorzqdu terytorialnego w konstytucji by Teresa Rabska published originally in Polish in the Journal of Law Economy and Sociology from 1995. The text is published as a part of a newly established section of the Adam Mickiewicz University devoted to the achievements of the late Professors of the Faculty of Law and Administration of the Adam Mickiewicz University, Poznań.

Keywords: Constitution of the Republic of Poland, public administration, local self-government.

Prof. Dr. Teresa Rabska, 1926-2018, Former Professor of Public Business Law, Vice-Rector of the Adam Mickiewicz University and Editorin-Chief of the Journal of Law, Economics and Sociology.

DOI 10.14746/ppuam.2020.11.01 